\title{
Transcobalamin from cow milk: isolation and physico-chemical properties
}

\author{
Sergey N. Fedosov a,b, Torben E. Petersen ${ }^{a}$, Ebba Nex $\varnothing^{\text {b,* }}$ \\ ${ }^{a}$ Protein Chemistry Laboratory, Department of Molecular Biology, University of Aarhus, Science Park, Gustav Wieds Vej 10, 8000 Aarhus C, Denmark \\ b Department of Clinical Biochemistry, KH University hospital of Aarhus, Norrebrogade 44, 8000 Aarhus C, Denmark
}

Received 8 March 1995; revised 11 July 1995; accepted 25 July 1995

\begin{abstract}
The concentration of endogenous cobalamin ( $\mathrm{Cbl}$ ) in cow milk was $3.3 \mathrm{nM}$ while the Cbl-binding capacity was $0.05 \mathrm{nM}$. Both endogenous and newly added $\mathrm{Cbl}$ showed similar quantitative distribution between a $280 \mathrm{kDa}$ protein complex $(45 \%)$ and a $43 \mathrm{kDa}$ Cbl-binder (55\%). Long time incubation, as well as urea treatment, was accompanied by a slow release of the $43 \mathrm{kDa} C b l-b i n d e r$ from the $280 \mathrm{kDa}$ fraction. No other Cbl-binding proteins appeared after these procedures. The $43 \mathrm{kDa}$ binder from cow milk, depleted of the ligand by urea treatment, reacted with $\mathrm{Cbl}$ even in the presence of a $\mathrm{B}_{12}$-analogue cobinamide ( $\mathrm{Cbi}$ ) at the ratio $\mathrm{Cbl}: \mathrm{Cbi}=1: 40$. The Stokes radius of the binder changed from $2.7 \mathrm{~nm}$ for the Cbl-free protein to $2.5 \mathrm{~nm}$ for the Cbl-saturated form and the Cbl-saturated binder was able to displace human transcobalamin (TC) from the TC-receptor. The interaction between the protein and Cbl was significantly suppressed at $\mathrm{pH} 2.0$. The $\mathrm{N}$-terminal sequence of the purified $43 \mathrm{kDa}$ Cbl-binder revealed homology with TC from human and rabbit plasma. In conclusion we have shown that $\mathrm{TC}$ is the main Cbl-binding protein in cow milk. This is surprising, since previous studies on human and rat milk have shown another Cbl-binder, apo-haptocorrin, to be the dominating Cbl-binding protein.
\end{abstract}

Keywords: Cobalamin; Cow milk; Isolation; Sequence; Transcobalamin

\section{Introduction}

Vitamin $\mathrm{B}_{12}$ or cobalamin $(\mathrm{Cbl})$ is important as a coenzyme for methylmalonyl-CoA mutase and methionine synthase [1]. The vitamin is synthesized only by microorganisms in different chemical forms classified as 'true' Cbl-forms and analogues [2,3]. The first group includes the forms of $\mathrm{Cbl}$ (e.g., cyano-Cbl, hydroxo-Cbl) which can be converted to the coenzymes after their incorporation into animal tissues. The other group includes cobinamide ( $\mathrm{Cbi}$ ) and pseudo- $\mathrm{B}_{12}$, which have no catalytic function, at least for animals. Nevertheless, some of the analogues compete with the coenzymes and suppress Cbl-dependent biochemical reactions $[4,5]$.

The uptake of $\mathrm{Cbl}$ from food and its dissemination

\footnotetext{
Abbreviations: $\mathbf{B}_{12}$, vitamin $\mathrm{B}_{12} ; \mathrm{Cbl}$, cobalamin; $\mathrm{Cbl}^{*}$, [ ${ }^{57}$ Co]cyanocobalamin; Cbi, dicyanocobinamide; $\mathrm{HC}$, haptocorrin; IF, intrinsic factor; TC, transcobalamin; $\mathrm{P}_{\mathrm{i}}$-buffer $\mathrm{NaH}_{2} \mathrm{PO}_{4} / \mathrm{Na}_{2} \mathrm{HPO}_{4}$ buffer.

${ }^{*}$ Corresponding author. Tel.: +4589 493083; Fax: +4589493060.

among animal tissues require the expression of three $\mathrm{Cbl}-$ binding proteins: intrinsic factor (IF), transcobalamin (TC) and haptocorrin (HC) [6,7]. Released from the food $\mathrm{Cbl}$ binds to gastric IF and the complex IF-Cbl enters the ileal mucosal cells by a receptor mediated mechanism [6-9]. $\mathrm{Cbl}$ is transferred inside the enterocytes from IF to TC and TC-Cbl, as well as unsaturated TC, is released into portal plasma [6,7,9-12]. Plasma TC-Cbl binds to specific receptors in the tissue $[6,7,13]$. The internalized $\mathrm{Cbl}$ is metabolized to the coenzymes: methyl-Cbl and 5'-deoxyadenosylCbl $[1,6,7]$.

The role of the third Cbl-binding protein $\mathrm{HC}$ is not completely clear. Its probable function in plasma is withdrawal of Cbl-analogues from the circulation, since $\mathrm{HC}$ has a high affinity to many Cbl-forms in contrast to TC and IF $[2,3,6,7]$. $\mathrm{HC}$ is a $\mathrm{pH}$-resistant protein that binds $\mathrm{Cbl}$ even at $\mathrm{pH}$ 1.5-2.0 while TC loses its Cbl-binding capacity at acidic $\mathrm{pH}$ [14].

Cbl-binding proteins are also present in excreted body fluids. Human and rat saliva and milk [15-17] contain a relatively high concentration of generally unsaturated $\mathrm{HC}$ $(30-100 \mathrm{nM})$ [15-18]. The physiological role of HC in 
excreted body fluids is unknown. An antibacterial function was proposed because apo-HC 'traps' $\mathrm{Cbl}$ in a form unaccessible for microorganisms $[2,6,7]$.

The Cbl-binders in cow milk have not been characterized so far. In the present paper we show that the main Cbl-binding protein in cow milk is transcobalamin and not haptocorrin as expected.

\section{Materials and methods}

\subsection{Cow milk and plasma gel filtration}

An aliquot of milk, collected from several thousand cows, was received from a dairy. The sample was centrifuged at $3000 \times g, 5^{\circ} \mathrm{C}$ for $10 \mathrm{~min}$ and the lipid fraction on the top was removed. Skim milk $(3 \mathrm{ml})$ or cow plasma $(1 \mathrm{ml}$ of plasma $+2 \mathrm{ml} 0.1 \mathrm{M} \mathrm{NaCl}$ ) was incubated either with 0.75 pmol of radioactive $\mathrm{Cbl}^{*}$ (Amersham, $3.9 \mathrm{kBq}$ per pmol) or with the mixture of $0.25 \mathrm{nM} \mathrm{Cbl}^{*}$ and $10 \mathrm{nM}$ Cbi (Sigma) for $5 \mathrm{~h}$ at room temperature. The sample was subjected to gel filtration on a $2 \times 83 \mathrm{~cm}$ Sephacryl S-200 column (Pharmacia) equilibrated with $0.1 \mathrm{M}$ Tris, $1 \mathrm{M}$ $\mathrm{NaCl}, 0.2 \%$ sodium azide ( $\mathrm{pH} \mathrm{8.0)}$ with an elution flow of $10-20 \mathrm{ml} / \mathrm{h}$ at room temperature. The protein profile was recorded as $A_{280}\left(E_{280}^{\mathrm{mg} / \mathrm{ml}} \approx 1\right)$ or $A_{293}\left(E_{293}^{\mathrm{mg} / \mathrm{ml}} \approx 0.5\right)$. The value of $A_{280}-A_{330}$ or $A_{293}-A_{330}$ was used for the turbid milk sample. $\mathrm{Cbl}^{*}$-containing radioactive fractions $(2.5-3 \mathrm{ml})$ were measured in a $\gamma$-counter.

\subsection{Determination of Stokes radius}

Stokes radius was determined by gel filtration on a $2.5 \times 100 \mathrm{~cm}$ Sephadex G-200 column (Pharmacia) according to Ackers [19]. All conditions were the same as described above for gel filtration on Sephacryl S-200.

\subsection{Determination of the Cbl-binding capacity}

The total amount of unsaturated Cbl-binders was determined by the method of Gottlieb et al. [20]. The solution with $0.05-0.2 \mathrm{nM}$ of unsaturated Cbl-binders was incubated with $0.25 \mathrm{nM} \mathrm{Cbl}^{*}$ for $1 \mathrm{~h}$ at room temperature. Afterwards, the free ligand was adsorbed on haemoglobin-coated charcoal, removed by centrifugation and the protein-associated radioactivity was measured in the supernatant. The determination of the unsaturated binding capacity in partially purified protein from cow milk was performed in the presence of $1 \mathrm{M} \mathrm{NaCl}$ in order to suppress adsorption of TC on haemoglobin-coated charcoal at low ionic strength [21].

The alternative way for the determination of Cbl-binding capacity was based on gel filtration. The assayed sample was diluted with $0.1 \mathrm{M}$ Tris, $1 \mathrm{M} \mathrm{NaCl}, 0.2 \%$ sodium azide ( $\mathrm{pH} 8.0$ ) to $0.05-0.2 \mathrm{nM}$ of unsaturated Cbl-binders. Then, $0.25 \mathrm{nM} \mathrm{Cbl}^{*}$ was added and after incubation for $1 \mathrm{~h}$ at room temperature the sample was applied to a Sephacryl S-200 column, see above.

\subsection{Determination of the endogenous $\mathrm{Cbl}$}

Quantification of $\mathrm{Cbl}$ was performed by an isotope dilution method [22]. The protein-bound Cbl (100-500 pM) was released by boiling at $\mathrm{pH} 4.8$ in the presence of $75 \mu \mathrm{M} \mathrm{KCN}$ and then subjected to competition with radioactive $\mathrm{Cbl}^{*}$ for IF or $\mathrm{HC}$. The IF-method measures the concentration of cobalamins in the assayed solution, while the HC-method measures the sum of cobalamins and analogues [23].

\section{5. $p H$ Stability of Cbl-binders}

Acid-resistant binding capacity in cow plasma was determined as follows. The plasma sample $(1 \mathrm{ml}$ of plasma $+2 \mathrm{ml} 0.1 \mathrm{M} \mathrm{NaCl}$ ) was loaded with radioactive $\mathrm{Cbl}^{*}$ as described above. Then, the $\mathrm{pH}$ of the sample was adjusted to 2.0 by $1 \mathrm{~N} \mathrm{HCl}$ and the mixture was incubated for 30 min at room temperature. The distribution of $\mathrm{Cbl}^{*}$ in protein fractions of the acidified plasma was traced by gel filtration on a Sephacryl S-200 column, see above.

The $\mathrm{pH}$ stability of the partially purified Cbl-binder loaded with $\mathrm{Cbl}^{*}$ was analyzed identically to plasma.

\subsection{Displacement of human TC from the human TC-recep- tor by Cbl-binder from cow milk}

The procedure of displacement was performed under the conditions described earlier [24]. The binding of 0.2 nM human TC saturated with $\mathrm{Cbl}^{*}$ to the TC-receptor from human placenta was carried out with or without $5 \mathrm{nM}$ Cbl-protein from cow milk. The $\mathrm{Ca}^{2+}$-sensitive specific binding was analyzed.

\subsection{Isolation of transcobalamin from cow milk}

Fresh skimmed milk (10 1) was mixed with $20 \mathrm{pmol}$ of radioactive $\mathrm{Cbl}^{*}$ and left for $2-3$ days at $2-5^{\circ} \mathrm{C}$.

The milk proteins were fractionated by $\left(\mathrm{NH}_{4}\right)_{2} \mathrm{SO}_{4}$ at $2-5^{\circ} \mathrm{C}$. The salt $(0.226 \mathrm{~kg} / \mathrm{l})$ was added to $10 \mathrm{l}$ of stirred milk in increments until $40 \%$ of saturation (1.6 M) was reached. This procedure took about $1 \mathrm{~h}$. The mixture was left for another $0.5 \mathrm{~h}$ for equilibration and then centrifuged at $5000 \times g, 2^{\circ} \mathrm{C}$ for $10 \mathrm{~min}$. The supernatant was collected. The bulky precipitate was suspended in 21 of $40 \%$-saturated $\left(\mathrm{NH}_{4}\right)_{2} \mathrm{SO}_{4}$-solution for additional extraction. The obtained suspension was centrifuged and the two supernatants $(\approx 10 \mathrm{l}$ ) were pooled. Then $0.187 \mathrm{~kg} / \mathrm{l}$ of $\left(\mathrm{NH}_{4}\right)_{2} \mathrm{SO}_{4}$ was added for $70 \%$-saturation. After $1.5 \mathrm{~h}$, the mixture was centrifuged at $5000 \times g, 2^{\circ} \mathrm{C}$ for $20 \mathrm{~min}$. The precipitate was collected and suspended in $250 \mathrm{ml}$ of 0.04 M $\mathrm{P}_{\mathrm{i}}$-buffer ( $\mathrm{pH}$ 7.5). The volume after dissolving was $\approx 500 \mathrm{ml}$. The main amount of the Cbl-binder in this 
preparation had a molecular mass of $43 \mathrm{kDa}$ as judged from gel filtration.

The obtained solution was prepared for $\mathrm{CM}$ ion-exchange chromatography by dialysing against 51 of $0.04 \mathrm{M}$ $\mathrm{P}_{\mathrm{i}}$-buffer, $\mathrm{pH} 7.5\left(24 \mathrm{~h}\right.$ at $5^{\circ} \mathrm{C}$ with one change of the buffer). Neutral $\mathrm{pH}$ of the adsorption medium was preferable to $\mathrm{pH} 5.2$ (conventionally used for human TC purification $[25,26])$. The dialysed sample $(\approx 700 \mathrm{ml})$ was applied to $2 \times 16 \mathrm{~cm} \mathrm{CM-Sepharose} \mathrm{column} \mathrm{(Pharmacia)}$ at room temperature with the flow of $40 \mathrm{ml} / \mathrm{h}$. The radioactive band drifted behind a coloured brownish protein during adsorption of the protein sample. We observed no drift during the following wash with $25 \mathrm{ml}$ of $0.04 \mathrm{M}$ $\mathrm{P}_{\mathrm{i}}$-buffer ( $\mathrm{pH} 7.5$ ). The next solution ( $70-150 \mathrm{ml}$ of 0.12 M $\mathrm{P}_{\mathrm{i}}$-buffer, $\mathrm{pH}$ 7.5) was applied until the brownish protein was completely removed from the matrix and the protein concentration in eluate became $0.3-0.5 \mathrm{mg} / \mathrm{ml}$. Afterwards, the Cbl-binder was desorbed in $0.2 \mathrm{M} \mathrm{P}_{\mathrm{i}}$-buffer, $\mathrm{pH} 7.5$ (flow rate $10 \mathrm{ml} / \mathrm{h}$ ).

The fractions with maximal $\mathrm{Cbl}^{*}$-radioactivity were pooled (final volume $\approx 15 \mathrm{ml}$ ). The sample was dialysed for 2 days at room temperature against $150 \mathrm{ml}$ of $8 \mathrm{M}$ urea dissolved in $0.2 \mathrm{M} \mathrm{P}_{\mathrm{i}}$-buffer ( $\mathrm{pH} 7.5$ ) with one change of the medium. $95-98 \%$ of endogenous $\mathrm{Cbl}$ was released into the external medium according to $\mathrm{Cbl}^{*}$-liberation. Protein renaturation was reached in 2 days during dialysis against 11 of $0.04 \mathrm{M} \mathrm{P}_{\mathrm{i}}$-buffer $\left(\mathrm{pH} 7.5\right.$ at $2-5^{\circ} \mathrm{C}$ ) with one change of the medium. The recovery of $\mathrm{Cbl}$-binder after renaturation was $30-50 \%$ as judged from the Cbl-binding capacity related to the amount of released $\mathrm{Cbl}$.

The Cbl-free protein was applied to a $2 \mathrm{ml}$ affinity column, prepared as previously described [27]. Adsorption of the sample was carried out at $2-5^{\circ} \mathrm{C}$ at a flow of $10-20$ $\mathrm{ml} / \mathrm{h}$. The matrix, containing adsorbed Cbl-binder, was washed in steps with: $10 \mathrm{ml}$ of $0.04 \mathrm{M} \mathrm{P}$-buffer $(\mathrm{pH} 7.5)$; $10 \mathrm{ml}$ of $0.2 \mathrm{M} \mathrm{P}_{\mathrm{i}}$-buffer (pH 7.5) and $20 \mathrm{ml}$ of $0.1 \mathrm{M}$ Tris, $1 \mathrm{M} \mathrm{NaCl}(\mathrm{pH} \mathrm{8.0)}$. The washed column was incubated at $37^{\circ} \mathrm{C}$ overnight for disruption of the thermolabile bond between the matrix and Cbl-protein. Desorbed Cbl-binder, together with the free hydroxo-Cbl, was eluted at $37^{\circ} \mathrm{C}$ in Tris $+\mathrm{NaCl}$ buffer. The coloured fractions were collected and pooled, final volume $\approx 3 \mathrm{ml}$.

The eluate from the affinity column was dialysed at $5^{\circ} \mathrm{C}$ against 11 of $10 \mathrm{mM} \mathrm{P}_{\mathrm{i}}$-buffer $(\mathrm{pH} \mathrm{7.5)}$ in order to remove free hydroxo-Cbl. The external solution was changed every $24 \mathrm{~h}$ until no spectral difference between the dialysing medium and the pure buffer was obtained. The procedure usually took 4 days. At this step, the protein concentration was measured according, to the peptide bond absorbance coefficient $E_{205}^{\mathrm{mg} / \mathrm{ml}}=31 \pm 2$ [28]. If the assayed solution had a light turbidity, measurement of $A_{205}-A_{250}$ was performed. The final dialysing medium was $100 \mathrm{ml}$ of 0.1 M Tris, $1 \mathrm{M} \mathrm{NaCl}(\mathrm{pH} 8)$. Then, the protein was applied to a Sephacryl S-200 column $(2 \times 83 \mathrm{~cm})$ equilibrated with the same buffer at room temperature. Protein elution was recorded at $230 \mathrm{nM}\left(E_{230}^{\mathrm{mg} / \mathrm{ml}} \approx 6\right)$ and the main peak of 43
$\mathrm{kDa}$ protein was collected for SDS-electrophoresis and $\mathrm{N}$-terminal sequence determination according to standard procedures [29].

\section{Results}

\subsection{Distribution of Cbl-binders in cow milk}

The Cbl-binding capacity in cow milk was $0.05 \pm 0.02$ $\mathrm{nM}(\bar{X} \pm$ S.D., $n=8)$ and the concentration of endogenous $\mathrm{Cbl}$ was $3.3 \pm 0.3 \mathrm{nM}(n=11)$. The determined Cbl-concentration was the same when measured employing IF and $\mathrm{HC}$ as the binding proteins. This indicates the absence of detectable analogues in cow milk [23].

The allocation of endogenous and radioactive $\mathrm{Cbl}$ was assayed during fractionation of $\mathrm{Cbl}^{*}$-treated milk. The same distribution of both Cbl's was observed employing the following methods of fractionation: gel filtration, acidic precipitation of milk proteins at $\mathrm{pH} 4.6,\left(\mathrm{NH}_{4}\right)_{2} \mathrm{SO}_{4}$-fractionation and ion-exchange chromatography. Therefore, protein-bound $\mathrm{Cbl}^{*}$ can be used as a measure of Cblsaturated proteins during milk fractionation.

Gel filtration of cow milk revealed two peaks of Cbl-binders, see Fig. 1A. One of them was associated with a bulky protein peak $\left(M_{\mathrm{r}} \approx 280 \mathrm{kDa}\right)$ and did not fit according to its molecular mass to any known Cbl-binder. The other peak had the same elution volume as TC $\left(M_{\mathrm{r}} \approx 43\right.$ $\mathrm{kDa})$. The $280 \mathrm{kDa}$ and the $43 \mathrm{kDa}$ peaks comprised $45 \pm 6 \%$ and $55 \pm 6 \%(n=8)$ of the milk Cbl-binders, respectively.

Incubation of a milk sample with a $\mathrm{Cbl}^{*}+\mathrm{Cbi}$ mixture showed similar low suppression of $\mathrm{Cbl}^{*}$-binding in both peaks, see Fig. 1A. It points to the absence of a considerable amount of the Cbi-sensitive apo-HC in cow milk.

The $280 \mathrm{kDa}$ Cbl-peak precipitated together with the caseins when milk was subjected to chymosin-treatment, acidification of the medium $(\mathrm{pH} \mathrm{4.6)}$ and $40 \%$ saturation with $\left(\mathrm{NH}_{4}\right)_{2} \mathrm{SO}_{4}(1.6 \mathrm{M})$. We failed to release a Cbl-binder from the isolated $280 \mathrm{kDa}$ complex by treatment with $20 \mathrm{mM}$ EDTA, $1 \mathrm{M} \mathrm{NaCl}$ or $0.1 \mathrm{mM} \mathrm{KCN}$ for several hours. However, incubation at $5^{\circ} \mathrm{C}$ was accompanied by a slow liberation $\left(\tau_{1 / 2}=17\right.$ days) of a $43 \mathrm{kDa}$ Cbl-binding protein, as judged by gel filtration.

Dialysis of a milk sample against $8 \mathrm{M}$ urea for 2 days increased the Cbl-binding capacity up to $0.4 \mathrm{nM}$ and decreased the concentration of endogenous $\mathrm{Cbl}$ down to 1 $\mathrm{nM}$. The urea treatment was also accompanied by a redistribution of Cbl-binders: $80 \%$ of the endogenous $\mathrm{Cbl}$ and $85 \%$ of the binding capacity were associated with the 43 $\mathrm{kDa}$ fraction. No additional $\mathrm{Cbl}$-binding protein appeared during the procedure. These observations led to the conclusion that the main Cbl-binder in cow milk had a molecular mass of $43 \mathrm{kDa}$ but approximately half was associated with other proteins in cow milk. 


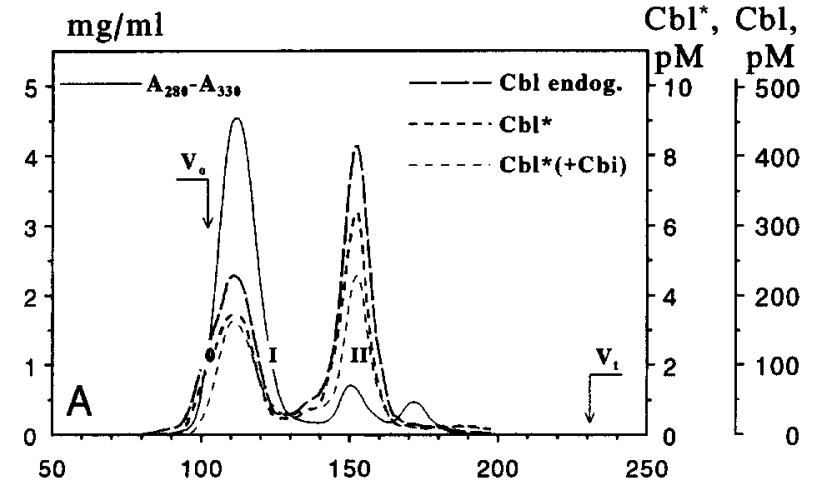

ml

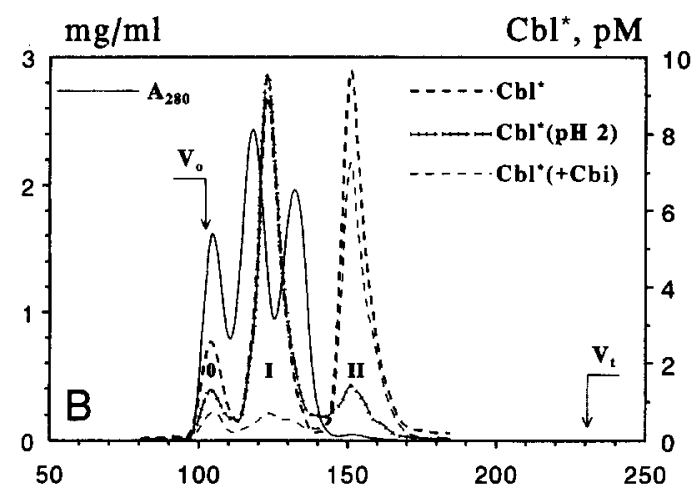

Fig. 1. Gel filtration on Sephacryl S-200 column $(2 \times 83 \mathrm{~cm})$. (A) Cow milk $(3 \mathrm{ml})$ and (B) cow plasma $(1 \mathrm{ml}$ plasma $+2 \mathrm{ml} 0.1 \mathrm{M} \mathrm{NaCl})$ were treated either with $0.25 \mathrm{nM} \mathrm{Cbl}^{*}(\ldots)$ or with $0.25 \mathrm{nM} \mathrm{Cbl}^{*}+10 \mathrm{nM}$ $\mathrm{Cbi}(-)$ for $5 \mathrm{~h}$ at room temperature. The $\mathrm{Cbl}^{*}$-profile $(+++)$ on (B) corresponds to a plasma sample treated with $\mathrm{Cbl}^{*}$ and then exposed to $\mathrm{pH} 2.0$ for $30 \mathrm{~min}$ prior to gel filtration. The profiles of the protein (-) and endogenous $\mathrm{Cbl}(--)$ are indicated. Numbers $\mathrm{O}$, I, II mark positions of cow plasma Cbl-binders both in (A) and in (B).

\subsection{Distribution of Cbl-binders in cow plasma}

The Cbl-binding capacity varied in cow plasma from $0.1 \mathrm{nM}$ to $0.3 \mathrm{nM}$ and the gel filtration profile of $\mathrm{Cbl}^{*}$ treated plasma (Fig. 1B) was similar to those obtained for other species $[10,11,30]$. Three peaks comprised the following amounts of the incorporated $\mathrm{Cbl}^{*}: 10 \%$ in peak 0 with $M_{\mathrm{r}}>500 \mathrm{kDa}, 40 \%$ in peak-I with $M_{\mathrm{r}} \approx 120 \mathrm{kDa}$ and $50 \%$ in peak-II with $M_{\mathrm{r}} \approx 43 \mathrm{kDa}$. The exposure of $\mathrm{Cbl}^{*}$-treated plasma to $\mathrm{pH} 2.0$ reduced the amount of $\mathrm{Cbl}^{*}$ eluted with peak II, Fig. 1B.

Quantification of endogenous $\mathrm{Cbl}$ in cow plasma was hampered because of an extreme stability of the $120 \mathrm{kDa}$ $\mathrm{Cbl}$-protein complex. Thus, $\mathrm{Cbl}^{*}$-loaded $120 \mathrm{kDa}$ binder retained $50-70 \%$ of $\mathrm{Cbl}^{*}$ even after boiling in the presence of $\mathrm{KCN}$. The concentration of endogenous $\mathrm{Cbl}$ attached to the $43 \mathrm{kDa}$ Cbl-binding protein was estimated as $0.1 \mathrm{nM}$.

The plasma sample was incubated with a mixture of $0.25 \mathrm{nM} \mathrm{Cbl}^{*}$ and $10 \mathrm{nM} \mathrm{Cbi}$ in order to characterize ligand specificity of the Cbl-binding proteins. Only partial suppression of $\mathrm{Cbl}^{*}$-binding by the analogue was observed

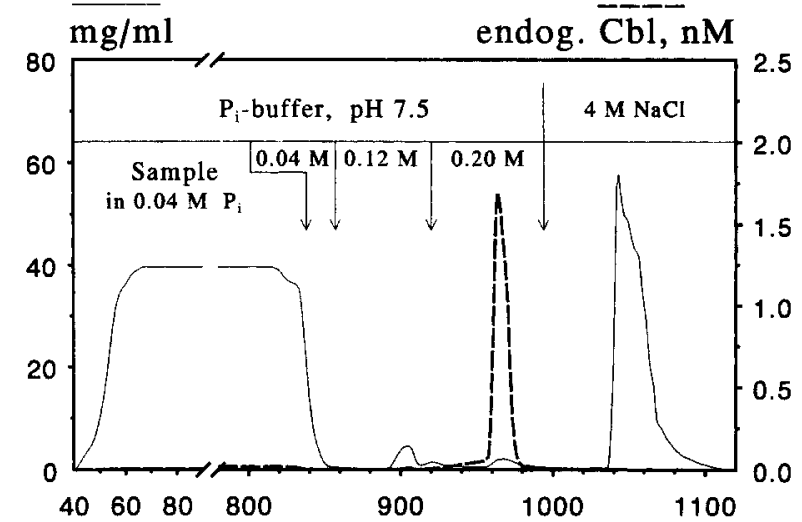

Fig. 2. CM-Sepharose chromatography profile of a Cbl-binding protein partially purified from cow milk. $700 \mathrm{ml}$ of the preparation, precipitated from cow milk between $40 \%$ and $70 \%$ of $\left(\mathrm{NH}_{4}\right)_{2} \mathrm{SO}_{4}$-saturation, was dialysed against $0.04 \mathrm{M} \mathrm{P}$-buffer ( $\mathrm{pH} \mathrm{7.5)} \mathrm{and} \mathrm{applied} \mathrm{to} \mathrm{a} 50 \mathrm{ml}$ $\mathrm{CM}$-Sepharose column. The elution profile was as indicated in the figure: (-) protein profile, $(--)$ profile of endogenous Cbl calculated from the direct measurements as well as from associated radioactivity.

in peaks 0 and II while radioactivity in peak I almost disappeared, Fig. 1B.

Molecular masses, $\mathrm{pH}$-stability and substrate specificity point to the following allocation of Cbl-binders in cow plasma: peak 0 , high molecular aggregate containing both TC and HC; peak I, HC; and peak II, TC.

\subsection{Purification of a Cbl-binding protein from cow milk}

We chose the $43 \mathrm{kDa}$ Cbl-binder from cow milk as the aim of isolation. The $280 \mathrm{kDa}$ aggregate, containing associated $43 \mathrm{kDa}$ Cbl-carrier, was ignored as a protein complex unaccessible for the preparative purposes. The procedure of isolation was complicated by the almost complete ligand saturation of the Cbl-binder, which precluded the direct application of affinity chromatography [25-27]. Therefore, the following purification strategy was attained. The $43 \mathrm{kDa}$ Cbl-binding protein underwent partial purification by $\left(\mathrm{NH}_{4}\right)_{2} \mathrm{SO}_{4}$ precipitation and CM-Sepharose ion-exchange chromatography, Fig. 2. Then, the sample was depleted of endogenous $\mathrm{Cbl}$ by dialysis against $8 \mathrm{M}$

Table 1

Purification of a Cbl-binding protein from cow milk

\begin{tabular}{lrrll}
\hline Step of isolation & $\begin{array}{l}\text { Total } \\
\text { volume } \\
(\mathrm{ml})\end{array}$ & $\begin{array}{l}\text { Total } \\
\text { protein } \\
(\mathrm{mg})\end{array}$ & $\begin{array}{l}\text { Total 43 } \\
\text { kDa TC } \\
(\mathrm{nmol})\end{array}$ & $\begin{array}{l}\text { Purific. } \\
\text { factor }\end{array}$ \\
\hline Skimmed milk & 10000 & 280000 & 18 & 1 \\
$\left(\mathrm{NH}_{4}\right)_{2} \mathrm{SO}_{4}$ precipitate & 750 & 30000 & 13 & 9 \\
$\mathrm{CM}$ ion-exchange & 15 & 25 & 9 & $1.2 \cdot 10^{4}$ \\
Urea treatment & 15 & 23 & 3.5 & $1.3 \cdot 10^{4}$ \\
Affinity column & 3 & 0.12 & 3 & $2.6 \cdot 10^{6}$ \\
S-200 gel filtration & 15 & 0.10 & 2.5 & $3.0 \cdot 10^{6}$ \\
\hline
\end{tabular}

*) The value represents the sum of protein-bound $\mathrm{Cbl}$ and Cbl-binding capacity in the $43 \mathrm{kDa}$ protein fraction. 


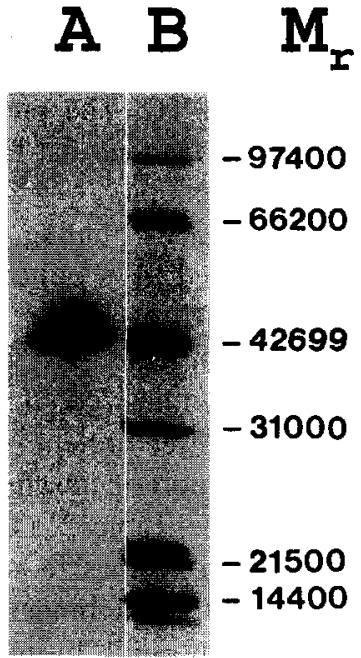

Fig. 3. SDS-polyacrylamide gel electrophoresis of (A) the Cbl-binding protein isolated from cow milk, (B) standard proteins. Molecular mass of the purified Cbl-binding protein is $43 \mathrm{kDa}$, as compared to the standards. The gel gradient is $10-20 \%$.

urea. Afterwards, the protein was subjected to affinity chromatography. The final gel filtration on Sephacryl S-200 had more analytical than preparative character.

The process of purification is described in Section 2 and summarized in Table 1.

The partially purified protein, depleted of endogenous Cbl by urea treatment, was examined concerning its ligand binding properties. The Cbl-binding protein decreased in size after Cbl-attachment and the Stokes' radii of its apoand holoforms were $2.7 \mathrm{~nm}$ and $2.5 \mathrm{~nm}$, respectively. The holoform was able to displace about $50 \%$ of human TC from the human TC-receptor under the experimental conditions. The unsaturated protein had a low affinity to Cbi (a $\mathrm{B}_{12}$-analogue) which is a feature of IF or TC. Thus, incubation with a mixture of $0.25 \mathrm{nM} \mathrm{Cbl}^{*}$ and $10 \mathrm{nM} \mathrm{Cbi}$ was accompanied only by $10-20 \%$ suppression of $\mathrm{Cbl}^{*}$ binding. The $\mathrm{Cbl}^{*}$-saturated $43 \mathrm{kDa}$ binder easily released the ligand at $\mathrm{pH} 2.0$. No protein associated radioactivity was found at $\mathrm{pH} 2.0$ as judged by charcoal-treatment and only $5-10 \%$ as judged by gel filtration.

The Cbl-binding protein obtained after affinity chromatography and gel filtration on Sephacryl S-200 was pure according to SDS-electrophoresis (Fig. 3). It had the molecular mass of $43 \mathrm{kDa}$ and the amount of bound $\mathrm{Cbl}$ was estimated as one mol per mol of the protein. The absorbance spectrum of the preparation showed peaks at $280 \mathrm{~nm}, 363 \mathrm{~nm}, 415 \mathrm{~nm}$ and $535 \mathrm{~nm}$. The ratio $A_{280} / A_{363}$ was estimated as 1.9 . Unfortunately, the low protein concentration precluded more careful spectral analysis.

The N-terminal sequence of the $43 \mathrm{kDa}$ Cbl-binder isolated from cow milk revealed its homology with human and rabbit $\mathrm{TC}[31-33]$ while similarity to $\mathrm{HC}$ from human plasma [34] was much less (Fig. 4). There was no ambiguity in the obtained $\mathrm{N}$-terminal sequence.

\section{Discussion}

We have purified and characterized the Cbl-binding protein in cow milk. It was classified as TC rather than $\mathrm{HC}$ because of the following reasons. N-terminal sequence revealed a homology between the isolated milk protein and TC from man and rabbit [31-33]. The protein decreased in size after Cbl-binding which is considered to be a characteristic feature [7]. The affinity to the Cbl-analogue ( $\mathrm{Cbi}$ ) was relatively low and could be estimated as at least 500-times less than that to Cbl. Low affinity to Cbi was earlier established for human and rabbit TC [2,3], while $\mathrm{HC}$ from these species was able to bind Cbi relatively well $[2,3]$. The complex between the protein and $\mathrm{Cbl}$ was unstable at $\mathrm{pH} 2.0$ which is also a feature of $\mathrm{TC}$ and not of

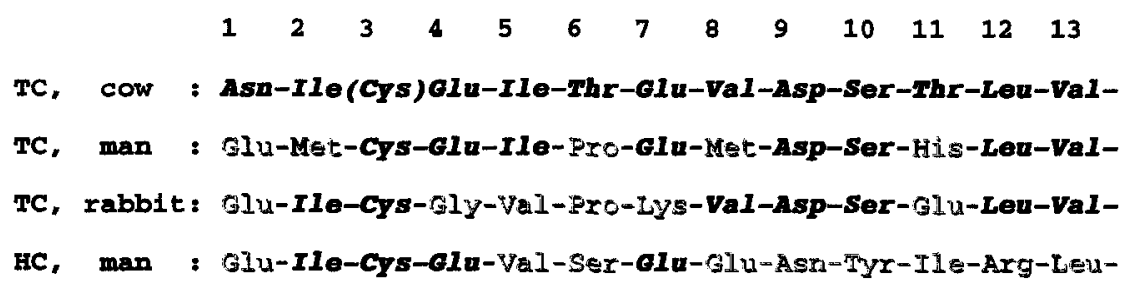

$\begin{array}{lllllllllllll}14 & 15 & 16 & 17 & 18 & 19 & 20 & 21 & 22 & 23 & 24 & 25 & 26\end{array}$

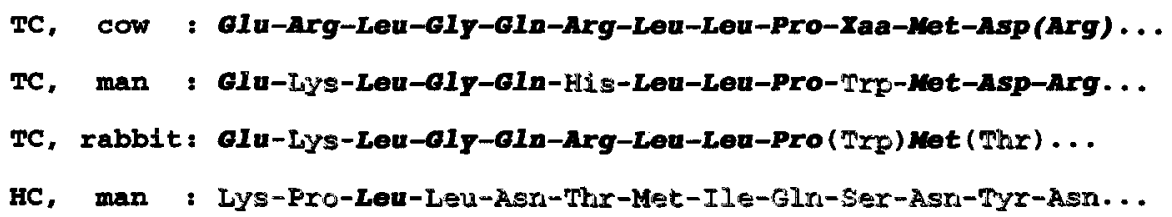

Fig. 4. N-terminal sequence of different Cbl-binders: TC from cow milk (present work), TC from human plasma [31,32], TC from rabbit plasma [33], HC from human plasma [34]. Amino-acid residues, equivalent to those in cow TC, are marked in bold letters. 
Table 2

The concentrations of apo- and holo-TC and HC in plasma and milk from different species

\begin{tabular}{llll}
\hline Protein & Cow $(\mathrm{nM})$ & Man $(\mathrm{nM})$ & rat $(\mathrm{nM})$ \\
\hline Plasma & present work & {$[6,7,10,11,30,36]$} & \\
HC & 0.08 & 0.2 & $-^{\mathrm{a}}$ \\
TD & 0.1 & 0.7 & 1.5 \\
HC-Cbl & $-^{\mathrm{a}}$ & 0.2 & $-^{\mathrm{a}}$ \\
TC-Cbl & 0.1 & 0.04 & $-^{\mathrm{a}}$ \\
Milk & present work & {$[15-18,35,36]$} & \\
HC & $\approx 0^{\mathrm{b}}$ & 90 & 20 \\
TC & 0.05 & 0.06 & $-^{\mathrm{a}}$ \\
HC-Cbl & $-^{\mathrm{a}}$ & 0.3 & $7^{\mathrm{a}}$ \\
TC-Cbl & 3.2 & $\approx 0 \mathrm{~b}$ & $-^{\mathrm{b}}$ \\
\hline
\end{tabular}

${ }^{\text {a }}$ No data available.

b $\approx 0-$ not detected

$\mathrm{HC}$ [14]. All the data provide an unambiguous proof that the Cbl-binder isolated from cow milk is TC and not HC.

The endogenous $\mathrm{Cbl}$ in cow milk showed an equal distribution between a large protein complex $(280 \mathrm{kDa})$ and TC (43 kDa). The high molecular mass complex liberated a $43 \mathrm{kDa}$ Cbl-containing protein during long time incubation and after urea treatment. It testifies that the Cbl-binding protein incorporated into $280 \mathrm{kDa}$ aggregate is, probably, the same $43 \mathrm{kDa}$ TC. Unsaturated $\mathrm{HC}$ was not detected, as concluded from the low affinity to $\mathrm{Cbi}$ in all milk fractions. Still, we cannot exclude the presence of $\mathrm{HC}-\mathrm{Cbl}$ in cow milk. Extreme stability of this complex, revealed in plasma preparations, provides a condition for its masking during Cbl-determination according to the standard procedure [22]

The total Cbl-binding capacity in cow milk was unusually low, when compared to other species, while the concentration of endogenous $\mathrm{Cbl}$ was intermediate between man and rat, Table 2. Cbl-analogues were not revealed in cow milk and the amount of TC-Cbl $(3 \mathrm{nmol}$ per liter) was quite sufficient to satisfy the demands of daily intake for man (1 nmol) [35]. The instability of TC-Cbl at $\mathrm{pH} 2$ guaranties the liberation of $\mathrm{Cbl}$ in acidic medium of human stomach and its binding to human IF and $\mathrm{HC}[37,38]$. It means that cow milk is an appropriate source of $B_{12}$ for man.

While rat and human milk contain mainly $\mathrm{HC}$, cow milk contains mainly TC. The different nature of Cbl-binders in milk from these species might be caused by their digestion distinctions. Thus, grass-eating animals have a strong dependence on microorganisms in their stomachs. A high concentration of unsaturated $\mathrm{HC}$ in milk might suppress the normal growth of the microorganisms due to 'trapping' of $\mathrm{Cbl}$ into the stable HC-Cbl complex. As a result of an evolutionary adaptation, grass-eating animals may have developed another way of Cbl-delivery by a less stable carrier, TC. Unfortunately, there is no available information in the literature about Cbl-binders in milk of other ruminants.
The gel filtration pattern of cow plasma was quite similar to human plasma. The main peaks of Cbl-binding capacity eluted as $\mathrm{HC}$ and TC. The presence of the two proteins was confirmed by the fact that $\mathrm{HC}$ bound $\mathrm{Cbi}$ and TC was sensitive to acidification.

The transport of $\mathrm{Cbl}$ and its binding protein from cow plasma to milk is unclarified. It is quite probable that the mechanism of $\mathrm{HC}$ and $\mathrm{TC}$ excretion into milk of the investigated species differs. Thus, $\mathrm{HC}$ in human and rat milk is supposed to be synthesized in mammary glands and excreted as a substrate-free protein [16,17]. It explains a relatively high concentration of unsaturated $\mathrm{HC}$ in milk as compared to plasma, see Table 2. On the other hand, there is no obvious need to synthesize new TC-Cbl in the mammary glands. The saturated binder might be transported from cow plasma into milk by the receptor-mediated mechanism $[6,7,13]$, provided that the TC-Cbl complex does not degrade inside the cells.

In conclusion, we have purified TC from cow milk and shown that $\mathrm{TC}$ rather than $\mathrm{HC}$ is the dominating Cbl-binding protein in cow milk. Further, our results indicate that cow milk is an excellent source of $\mathrm{Cbl}$ for human beings due to a relatively high concentration of $\mathrm{Cbl}$ and due to the absence of $\mathrm{B}_{12}$-analogues.

\section{Acknowledgements}

The authors appreciate greatly the perfect technical assistance of A.L. Christensen and A. Boisen. We are grateful to Andreas Madsen, MD Foods Research and Development Centre, Brabrand, Denmark, for the supply of bovine milk samples.

This work is a part of the FØTEK programme supported by the Danish Government and the Danish Dairy Board.

\section{References}

[1] Barker, H.A. (1972) Annu. Rev. Biochem. 41, 55-90.

[2] Kolhouse, J.F. and Allen, R.H. (1977) J. Clin. Invest. 60, 1381-1392.

[3] Stupperich, E. and Nexø, E. (1991) Eur. J. Biochem. 199, 299-303

[4] Coates, M.E., Davies, M.K. and Harrison, G.F. (1960) Arch. Biochem. Biophys. 87, 93-99.

[5] Siddons, R.C., Spence, J.A. and Dayan, A.D. (1975) Adv. Neurol. 10, 239-252.

[6] Allen, R.H. (1975) Prog. Hematol. 9, 57-84

[7] Nexø, E. and Olesen, H. (1982) in $B_{12}$ (Dolphin, D., ed.), Vol.II, pp. 57-85, Wiley, New York

[8] Smolka, A. and Donaldson, R.M., Jr. (1990) Gastroenterology 98, 607-614.

[9] Ramanujam, K.S., Seetharam, Sh., Ramasamy, M. and Seetharam, B. (1991) Am. J. Physiol. 260, G416-G422.

[10] Hom, B.L. (1967) Clin. Chim. Acta 18, 315-317.

[11] England, J.M., Down, M.C., Wise, I.J. and Linnell, J.C. (1976) Clin. Sci. Mol. Med. 51, 47-52.

[12] Wickramasinghe, S.N. and Fida. S. (1993) J. Clin. Patol. 46, 537539. 
[13] Quadros, E.V., Sai, P. and Rothenberg, Sh. (1994) Arch. Biochem. Biophys. 308, 192-199.

[14] Gilbert, H.S. (1977) J. Lab. Clin. Med. 89, 13-24.

[15] Burger, R.L. and Allen, R.H. (1974) J. Biol. Chem. 249, 7220-7227.

[16] Raaberg, L., Nexø, E., Poulsen, S.S. and Tollund, L. (1989) Scand. J. Clin. Lab. Invest. 49, 529-535.

[17] Nexø, E. (1990) in Biomedicine and Physiology of Vitamin $B_{12}$ (Linnel, J.C. and Bhatt, H.R., eds.), pp. 353-358, The Children's Med. Charity, London.

[18] Trugo, N.M.F. and Sardinha, F. (1994) Nutr. Res. 14, 23-33.

[19] Ackers, G.K. (1964) Biochemistry 3, 723-30.

[20] Gottlieb, C., Lau, K.-S., Wasserman, L.R. and Herbert, W. (1965) Blood 25, 875-884.

[21] Jacob, E. and Wong, K.T. (1983) J. Clin. Pathol. 36, 1022-1027.

[22] Nexø, E., Gimsing, P. (1981) Scand. J. Clin. Lab. Invest. 41, 465-468.

[23] Muir, M. and Chanarin, I. (1983) Br. J. Haematol. 54, 613-621.

[24] Nexø, E. and Hollenberg, (1980) Biochim. Biophys. Acta 628, 190-200.

[25] Van Kapel, J., Loef, B.G., Lindemans, J. and Abels, J. (1981) Biochim. Biophys. Acta. 676, 307-313.

[26] Quadros, E.V. and Rothenberg, Sh.P. (1986) J. Biol. Chem. 261, $15455-15460$

[27] Nexø, E. (1975) Biochim. Biophys. Acta 379, 189-192.
[28] Stoscheck, Ch.M. (1990) in Methods in Enzymology (Deutscher, M.P., ed.), Vol. 182, pp. 50-68, Academic Press, San Diego, CA.

[29] Rasmussen, L.K. and Petersen, T.E. (1991) J. Dairy Res. 58, $187-$ 193.

[30] Hall, Ch.A. and Finkler, A.E. (1971) in Methods in Enzymology (McCormick, D.B. and Wright, L.D., eds.), Vol. XVIII, part C, pp. 108-129, Academic Press, New York.

[31] Platica, O., Janeszko, R., Quadros, E.V., Regec, A., Romain, R. and Rothenberg, Sh.P. (1991) J. Biol. Chem. 266, 7860-7863.

[32] Li, N., Seetharam, Sh., Lindemans, J., Alpers, D., Arwert, F. and Seetharam, B. (1993) Biochim. Biophys. Acta 1172, 21-30.

[33] Nexø, E, Olsen, H., Bucher, D. and Thomsen, J. (1977) Biochim. Biophys. Acta 494, 395-402.

[34] Johnston, J., Bollekens, J., Allen, R.H. and Berliner, N. (1990) J. Biol. Chem. 264, 15754-15757.

[35] Sandberg, D.P., Begley, J.A. and Hall, C.A. (1981) Am. J. Clin. Nutr. 34, 1717-1724.

[36] Linnell, J.C. (1975) in Cobalamin, Biochemistry and Pathophysiology (Babior, B.M., ed.), Chap. 6, pp. 287-333, Wiley, New York

[37] Allen, R.H., Seetharam, B., Podell, E.R. and Alpers, D.H. (1977) J. Clin. Invest. 61, 47-54.

[38] Allen, R.H., Seetharam, B., Allen, N.C., Podell, E.R. and Alpers, D.H. (1978) J. Clin. Invest. 61, 1628-1634. 